\title{
Truncated phosphonated C-1'-branched N,O-nucleosides: A new class of antiviral agents
}

\author{
Roberto Romeo ${ }^{\mathrm{a}, *}$, Caterina Carnovale ${ }^{\mathrm{a}}$, Salvatore V. Giofrè ${ }^{\mathrm{a}}$, Giovanni Romeo ${ }^{\mathrm{a}}$, Beatrice Macchi ${ }^{\mathrm{b}}$, \\ Caterina Frezza ${ }^{b}$, Francesca Marino-Merlo ${ }^{c}$, Venerando Pistarà ${ }^{d}$, Ugo Chiacchio ${ }^{d}$ \\ a Dipartimento Farmaco-Chimico, Università of Messina, 98168 Messina, Italy \\ ${ }^{\mathrm{b}}$ Dipartimento di Neuroscienze, Università di Roma 'Tor Vergata', 00133 Roma, Italy \\ ${ }^{\mathrm{c}}$ Dipartimento di Scienze della vita, Università di Messina, 98100 Messina, Italy \\ ${ }^{\mathrm{d}}$ Dipartimento di Scienze del Farmaco, Università di Catania, 95125 Catania, Italy
}

\section{A R T I C L E I N F O}

\section{Article history:}

Received 23 December 2011

Revised 21 March 2012

Accepted 22 March 2012

Available online 29 March 2012

\section{Keywords:}

C-1'-branched N,O-nucleosides

1,3-Dipolar cycloaddition

Antiviral agents

HIV in vitro infections

MTS assay

\begin{abstract}
A B S T R A C T
Truncated phosphonated C-1'-branched N,O-nucleosides have been synthesized in good yields by 1,3dipolar cycloaddition methodology, starting from $N$-methyl-C-(diethoxyphosphoryl)nitrone 7. Preliminary biological assays show that $\beta$-anomers are able to inhibit HIV in vitro infection at concentrations in the micromolar range. Higher SI values with respect to AZT indicated that the compounds were endowed with low cytotoxicity.
\end{abstract}

(c) 2012 Elsevier Ltd. All rights reserved.

\section{Introduction}

Natural psicofuranosyl nucleosides, bearing a hydroxymethyl group at the anomeric carbon atom, have been reported to possess different and relevant biological activities. ${ }^{1}$ Typical examples are represented by angustmycin A $\mathbf{1}$ and $\mathrm{C} \mathbf{2}$, which show interesting antimicrobial and antiviral properties, ${ }^{2}$ and by hydantocidin 3, a spironucleoside, which exhibits herbicidal activity, able to regulate plant growth ${ }^{3}$ (Fig. 1). Besides their potential biological activity as antiviral agents, the $\mathrm{C} 1^{\prime}$-branched nucleosides show further great interest, linked to the availability of model nucleosides which may allow the study of the formation and evolution of radical species generated during DNA/RNA damage. ${ }^{4}$

N,O-psiconucleosides $\mathbf{4}$ constitute a particular class of modified psiconucleosides where an isoxazolidine system mimics the ribose ring of natural nucleosides and a hydroxymethyl group is linked at the anomeric carbon atom. ${ }^{5}$ These derivatives show synthetic interest for their potential antiviral or anticancer activity which have been also discovered in other N,O-nucleosides. ${ }^{6-11}$

Our research group has reported a versatile route towards the synthesis of N,O-psiconucleosides both in racemic and in enantiopure form. $5,12-15$

\footnotetext{
* Corresponding author.

E-mail address: robromeo@unime.it (R. Romeo).
}

More recently, the use of a chiral auxiliary has promoted the enantioselective synthesis of a series of psiconucleosides. ${ }^{16}$ However, none of the reported compounds has shown a remarkable biological activity, probably due to the lack of efficient phosphorylation towards the triphosphate derivatives, the active form of nucleoside RT inhibitors.

In the field of nucleoside analogs, N,O-modified nucleosides have been proved to efficiently block the in vitro and in vivo virus infections caused by HIV, HBV, and HTLV- $1 .{ }^{17-22}$ Following intracellular phosphorylation to their 5'-triphosphate forms, they are able to serve as chain terminators, thus acting as inhibitors in the viral reverse transcription reaction. ${ }^{18,19}$ Several strategies to overcome the initial selective phosphorylation step have been designed; ${ }^{23}$ in particular, phosphonate analogues, ${ }^{20}$ by miming the nucleoside monophosphates, overcome the instability of nucleotides towards phosphodiesterase and enhance the cellular uptake by bypassing the initial phosphorylation step.

In this context, we have recently reported the synthesis of phosphonated carbocyclic 2'-oxa-3'-azanucleosides (PCOANS) 5, which have shown to be potent inhibitors of RT of different retroviruses ${ }^{21}$ (Fig. 2). Also truncated phosphonated azanucleosides (TPCOANS) 6 , where the phosphonate group is directly linked to the $C-4^{\prime}$ position of the pseudosugar moiety, are able to inhibit the HIV and HTLV-1 viruses at concentration in the nanomolar range, with a potency comparable with that of Tenofovir. ${ }^{22}$ 


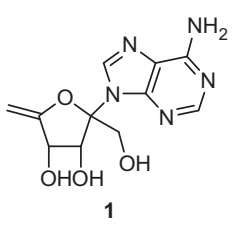

Angustmycin A<smiles>O=C1NC(=O)C2(N1)OC(CO)C(O)C2O</smiles>

Hydantocidin

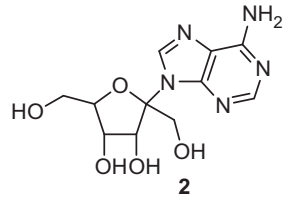

Angustmycin C

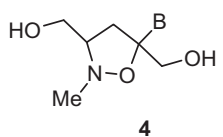

N,O-Psiconucleosides
Figure 1. Modified nucleosides, $B$ = nucleobase .<smiles>CC(Cn1cnc2c(N)ncnc21)OCP(=O)(O)O</smiles><smiles>[R]C1C(O)COC1[B]</smiles>

Truncated Nucleosides

$$
\mathrm{R}=\mathrm{H}, \mathrm{OH}
$$

$\mathrm{B}=$ purine or pyrimidine nucleobases<smiles>[B]C1CC(CP(=O)(OCC)OCC)N(C)O1</smiles>

PCOANS

$\mathrm{B}=\mathrm{Ty}, 5-\mathrm{Fu}, \mathrm{Cy}$

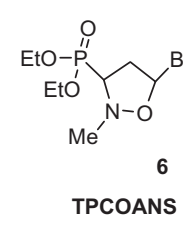

$\mathrm{B}=\mathrm{Ty}, 5-\mathrm{Fu}$

Figure 2. Tenofovir, truncated nucleosides and phosphonated N,O-nucleosides.

In connection with our work addressed to the search of new and potent antiviral agents, we have extended our interest to the synthesis of the new generation of truncated phosphonated $C-1^{\prime}$ branched N,O-nucleosides. The rational of our choice is based on the consideration that the presence of the phosphonic unit could bypass the limiting monophosphorylation step, thus promoting the cellular uptake and leading to biologically active compounds. We report in this paper the synthetic approach towards these derivatives and their preliminary biological evaluation. To the best of our knowledge, no example of this kind of compounds has been reported in the literature until now.

\section{Results and discussion}

\subsection{Chemistry}

According to the retrosynthetic analysis shown in Scheme 1, the key step of the synthetic route involves the 1,3-dipolar cycloaddition of the $\mathrm{N}$-methyl-C-(diethoxyphosphoryl)nitrone $\mathbf{7}$ with the acrylate $\mathbf{8}$.

The nitrone $\mathbf{7}$ can be prepared from the commercially available diethyl hydroxymethyl phosphonate $\mathbf{1 3}$ (route a), as previously described. ${ }^{24}$ We have designed an alternative methodology towards 7 (route b), which is based on the conversion of the phosphonated alcohol 13 into the corresponding mesylate 15; the subsequent reaction with $N$-methyl hydroxylamine afforded the derivative $\mathbf{1 6}$ which, by oxidation with $\mathrm{MnO}_{2}$, gave the target nitrone 7 in a $60 \%$ yield (Scheme 2 ).

In comparison to the route $A$, this second approach is performed in milder conditions, at room temperature, thus allowing to avoid

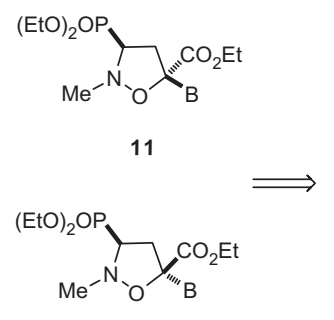

12<smiles>CCOC(=O)OC1(C)CC([Po](C)=O)ON1C</smiles>

9<smiles>CCOC(=O)C1CC(OCC)(OCC)ON1C</smiles>

10<smiles>CCOP(=O)(C=[N+]([O-])[O-])OCC</smiles>

7<smiles>C=C(OCC)OCC</smiles>

8
Scheme 1. Retrosynthetic analysis of truncated phosphonated N,Opsiconucleosides.

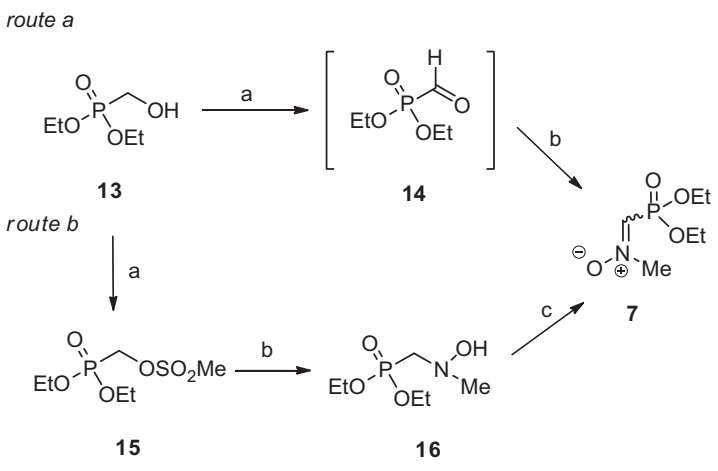

Scheme 2. Synthesis of phosphonated nitrone 7. Reagents and conditions route a: (a) Swern oxidation; (b) $\mathrm{MeNHOH} \cdot \mathrm{HCl}, \mathrm{Et}_{3} \mathrm{~N},-78^{\circ} \mathrm{C}$; route b: (a) $\mathrm{MeSO}_{2} \mathrm{Cl}_{2} \mathrm{CH}_{2} \mathrm{Cl}_{2}$, $\mathrm{Et}_{3} \mathrm{~N}, \mathrm{rt}$; (b) $\mathrm{Et}_{3} \mathrm{~N}, \mathrm{MeNHOH}$, reflux, $6 \mathrm{~h}$; (c) $\mathrm{MnO}_{2}, \mathrm{CH}_{2} \mathrm{Cl}_{2}$.

the severe experimental conditions required by the Swern oxidation $\left(-78^{\circ} \mathrm{C}\right)$ and the possible decomposition of intermediate 14 to carbon monoxide and dialkyl phosphate, with the risk of explosion, during the work up.

Dipolarophile 8 has been prepared starting from ethyl pyruvate, by heating with acetic anhydride., 5 The cycloaddition of $\mathbf{7}$ with ethyl 2-acetyloxyacrylate 8, in THF at reflux for $24 \mathrm{~h}$, afforded a mixture of cis/trans isoxazolidines $\mathbf{9}$ and $\mathbf{1 0}$ in an isomeric ratio of $1: 4.5$ and a combined yield of $80 \%$ (Scheme 3 ).

The crude reaction mixture was purified by flash chromatography $\left(\mathrm{CH}_{2} \mathrm{Cl}_{2} / \mathrm{Me}_{2} \mathrm{CHOH}\right.$ 98:2 as eluent) and two cycloadducts 9 and $\mathbf{1 0}$ were obtained in pure form. The cis/trans stereochemistry of both adducts was deduced on the basis of ${ }^{1} \mathrm{H}$ NMR spectroscopy and by means of NOE experiments. Thus, in the major trans compound 10, the resonance of $\mathrm{H}_{4 \mathrm{a}}$ appears as ddd at $2.85 \mathrm{ppm}$, while $\mathrm{H}_{4 b}$ resonates at $2.96 \mathrm{ppm}$ (ddd). Moreover, $\mathrm{H}_{3}$ resonates as ddd at $3.27 \mathrm{ppm}$. For the cis compound $\mathbf{9}$, the resonance of $\mathrm{H}_{4 \mathrm{a}}$ and $\mathrm{H}_{4 \mathrm{~b}}$ appears as ddd at 2.81 and $2.93 \mathrm{ppm}$ respectively; $\mathrm{H}_{3}$ resonates as ddd at $3.23 \mathrm{ppm}$. NOE difference experiments were conclusive in the stereochemical assignment: (a) on irradiation at $2.96 \mathrm{ppm}$ $\left(\mathrm{H}_{4 \mathrm{~b}}\right.$ of trans compound 10), a diagnostic positive NOE was observed for $\mathrm{H}_{3}(\delta=3.27 \mathrm{ppm})$ and the methyl of the OAc group, thus confirming their cis relationship, and (b) on irradiation of $\mathrm{H}_{4 \mathrm{~b}}$ of cis derivative 9, at $\delta=2.93 \mathrm{ppm}$, a positive NOE was observed for $\mathrm{H}_{3}$ $(\delta=3.23 \mathrm{ppm})$ but not for the methyl protons of OAc group.
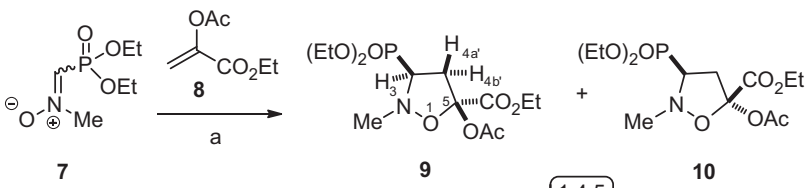

$1: 4.5$

Scheme 3. Cycloaddition reaction. Reagents and conditions: nitrone 7, ethyl 2acetyloxyacrylate 8 , THF, reflux, 24 h, overall yield $80 \%$. 


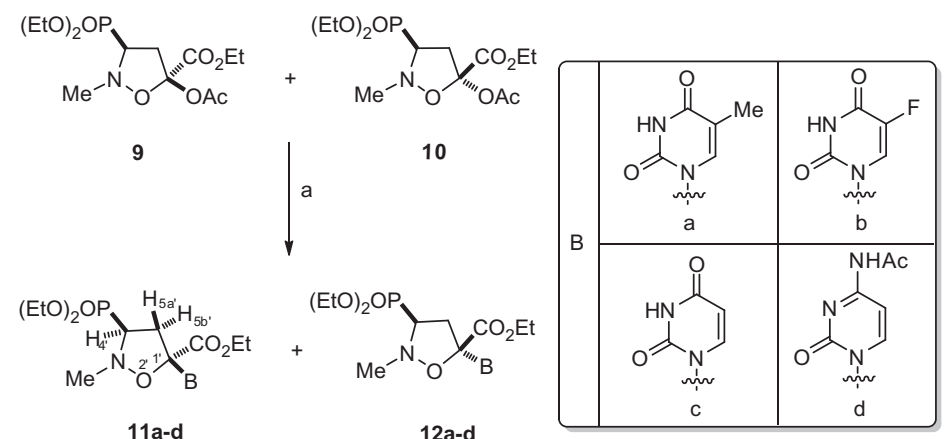

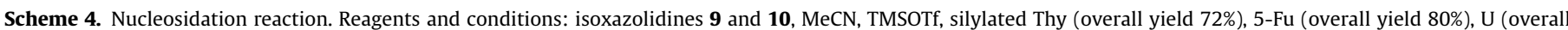
yield $71 \%$ ), or Ac-Cy (overall yield $61 \%$ ).

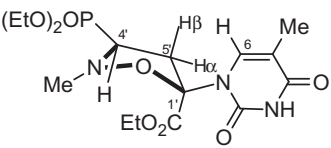

Figure 3. Preferred conformation of 11a.

The crude mixture of isoxazolidines $\mathbf{9}$ and $\mathbf{1 0}$ was then transformed into the pyrimidine nucleoside analogues 11 and 12, as depicted in Scheme 4.

The condensation with silylated thymine, uracil or acetylcytosine, using the glycosylation methodology developed by Vorbrüggen, resulted in nucleoside products consisting of $\beta-\mathbf{1 1 a}, \mathbf{c}, \mathbf{d}$ and $\alpha-12 a, c, d$ anomers in a $3: 2$ ratio and in $61-80 \%$ combined yield. The nucleosidation reaction performed with 5-fluoruracil showed a better diastereoselectivity in favor of the $\beta$-anomer $\mathbf{1 1 b}(\beta / \alpha$ ratio $4: 1$; combined yield: $85 \%$ ).

The ratio between $\alpha$ and $\beta$ nucleosides did not change if the nucleosidation was performed starting from the separated cis/trans isoxazolidines $\mathbf{9}$ and $\mathbf{1 0}$. As previously reported for similar compounds, ${ }^{13}$ these results indicate that the coupling reaction occurs without selectivity with respect to the anomeric center. The anomers have been separated by flash chromatography, the cis isomer $(\beta)$ showing the lower rf. The anomeric configuration of obtained modified nucleosides was assigned on the basis of ${ }^{1} \mathrm{H}$ NMR and NOE experiments.

The ${ }^{1} \mathrm{H}$ NMR spectrum of the major isomer 11a, chosen as reference, showed a different set of signals in comparison with 12a. In particular, the $\mathrm{H} 4^{\prime}$ proton resonated at $3.25 \mathrm{ppm}$ (ddd), $\mathrm{H}^{\prime} \beta$ at $2.93 \mathrm{ppm}$ (ddd) and $\mathrm{H}^{\prime} \alpha$ at $3.28 \mathrm{ppm}$ (ddd). Positive NOE effects were observed within $\mathrm{H}^{\prime} \beta-\mathrm{H} 6$ and $\mathrm{H}^{\prime}-\mathrm{H}^{\prime} \alpha$ pairs of protons and fully supported the cis configuration of the substituents at $\mathrm{C}^{\prime}$ ' (thymine) and C4' (diethoxyphosphoryl) in the $\beta$ isomer 11a. Analogous NOE effects have been detected for the fluorouracil, uracil and cytosine derivatives 11b-d.

Since values of all vicinal coupling constants were successfully extracted from the ${ }^{1} \mathrm{H}$ and ${ }^{13} \mathrm{C}$ NMR spectra of 11a, detailed conformational analysis was accomplished. On the basis of vicinal couplings $\left[J\left(\mathrm{H}-\mathrm{C} 4^{\prime}-\mathrm{C}^{\prime} \mathrm{H} \beta\right)=10.5 \mathrm{~Hz}, J\left(\mathrm{H}^{-C} 4^{\prime}-\mathrm{C}^{\prime} \mathrm{H} \alpha\right)=8.5 \mathrm{~Hz}\right.$, $J\left(\mathrm{P}-\mathrm{C} 4^{\prime}-\mathrm{C} 5^{\prime} \beta\right)=16.5 \mathrm{~Hz}, J\left(\mathrm{P}-\mathrm{C} 4^{\prime}-\mathrm{C}^{\prime} \alpha\right)=4.0 \mathrm{~Hz}, J\left(\mathrm{C} 1^{\prime}-\mathrm{C}-\mathrm{C}-\mathrm{P}\right)=$ $11.5 \mathrm{~Hz}$ ] it was concluded that the isoxazolidine ring exists in an $E_{1}$, conformation in which the thymine residue occupies the equatorial position, while the ethoxyphosphoryl group is located pseudoequatorially (Fig. 3).

\subsection{Biological results}

For testing the potential activity of the new truncated phosphonated $\mathrm{C}-1^{\prime}$-branched $\mathrm{N}, \mathrm{O}$-nucleosides against human retroviruses, we assessed their ability to inhibit both HIV and HTLV-1 in vitro
Table 1

Inhibitory activity of the compounds 11a-d on HIV infection

\begin{tabular}{llll}
\hline Compound & HIV infection $\mathrm{IC}_{50}{ }^{\mathrm{a}}(\mu \mathrm{M})$ & $\mathrm{SI}^{\mathrm{b}}$ & $\mathrm{CC}_{50}$ Molt- $3^{\mathrm{c}}(\mu \mathrm{M})$ \\
\hline $\mathbf{1 1 a}$ & $>1000$ & $\mathrm{n} . \mathrm{d}$ & $>1000$ \\
$\mathbf{1 1 b}$ & 220 & 4.5 & $>1000$ \\
$\mathbf{1 1 c}$ & 132 & 7.57 & $>1000$ \\
$\mathbf{1 1 d}$ & $>1000$ & n.d. & $>1000$ \\
$\mathbf{1 1 e}$ & 180 & 7.02 & $>1000$ \\
AZT & 7.7 & 1.57 & 12.1 \\
\hline
\end{tabular}

a $\mathrm{IC}_{50}$ : inhibitory concentration required to inhibit $50 \%$ HIV infection.

b SI: selectivity index based on the ratio $\mathrm{CC}_{50} / \mathrm{IC}_{50}$.

${ }^{C} C_{50}$ is the cytotoxic concentration $50 \%$ required to inhibit $50 \%$ metabolic activity evaluated in cell line MOLT-3 by MTS.

infections. Zidovudine (AZT) was used as an internal positive control in the assay, since it is the prototype of nucleoside inhibitors of HIV reverse transcriptase, acting as chain terminator, equally active in comparison with other nucleoside and nucleotide analogues, towards HIV in vitro infection ${ }^{22}$ The results reported in Table 1 showed that compounds 11a and 11d were not active, while 11b and 11c inhibited HIV infection at an inhibitory concentration $50\left(\mathrm{IC}_{50}\right)$ of 220 and $132 \mu \mathrm{M}$ respectively. Conversely AZT showed an $\mathrm{IC}_{50} 28$ times lower in comparison with that of the tested compounds. On the other hand, the compounds were unable to inhibit HTLV-1 infection (data not shown). Moreover, cytotoxicity indicated that 11b and 11c $\left(\mathrm{CC}_{50}>1000 \mu \mathrm{M}\right)$ were at least eighty three times less cytotoxic than AZT $\left(\mathrm{CC}_{50} 12.1 \mu \mathrm{M}\right)$, as demonstrated by the values of cytotoxic concentration $50\left(\mathrm{CC}_{50}\right)$ shown in Table 1. Actually this is summarized by the values of the selectivity index ( $\mathrm{SI}$ ) calculated on the basis of the ratio between the $\mathrm{CC}_{50}$ and $\mathrm{IC}_{50}$ values. Table 1 shows the comparison between the anti HIV activity of $\mathbf{1 1 b}$ and 11c versus AZT, by reporting the SI for each compound. The SI of 11c, (7.6) was higher than that of 11b (4.5) and than that of AZT (1.57). A high SI value indicated that the compounds were endowed with low cytotoxicity.

Thus, the low cytotoxic effect of the compounds could balance their higher $\mathrm{IC}_{50}$ with respect to the positive control. In addition, the activity of 11b and 11c seems to be rather specific toward HIV infection, since they were unable to inhibit HTLV-1 infection (data not shown). Moreover, it is interesting to put in evidence that compounds 12a-d did not show any activity against HIV and HTLV-1 viruses, in agreement with the $\alpha$-nature of these derivatives.

\section{Conclusion}

Truncated phosphonated C-1'-branched N,O-nucleosides have been synthesized in good yields by the 1,3-dipolar cycloaddition methodology, starting from the nitrone 7. Preliminary biological 
assays show that the $\beta$-anomers are able to inhibit infection of HIV at concentrations in the micromolar range. Although twenty eight times less active than AZT, they are certainly less cytotoxic than AZT, as deduced from the calculated SI values. In addition, they seem to be rather specific in inhibiting HIV infection, while they were unable to exert the same effect on HTLV-1 infection.

Truncated phosphonated represent a new template of cyclic nucleoside analogs which deserve further investigations as lead compounds for extending the current spectrum of antiviral activity of modified nucleosides, avoiding some unwanted side effects.

\section{Experimental section}

Melting points were recorded on a capillary melting point apparatus and are uncorrected. Elemental analyses were recorded on a Perkin-Elmer elemental analyzer. The elemental analyses of all final compounds were within $\pm 0.4 \%$ of the expected values. NMR spectra were performed on a Varian instrument at $500 \mathrm{MHz}(1 \mathrm{H})$ and at $125 \mathrm{MHz}$ (13C) using deuterochloroform; chemical shifts are given in ppm from TMS. The NOE difference spectra were obtained by subtracting alternatively right off-resonance free induction decays (FIDS) from right-on-resonance-induced FIDS. Thin-layer chromatographic separations were performed on Merck silica gel 60-F254 precoated aluminum plates. Preparative separations were carried out by flash chromatography using Merck silica gel $0.035-0.070 \mathrm{~mm}$. All reagents were purchased from Aldrich Chemicals Ltd.

\subsection{Synthesis of $\mathbf{N}$-methyl-C-(diethoxyphosphoryl) nitrone 7}

To a solution of diethyl hydroxymethyl phosphonate $(500 \mathrm{mg}$, $2.97 \mathrm{mmol})$ in dry dichloromethane $(20 \mathrm{~mL})$, triethylamine $(2.4 \mathrm{~mL}, 17 \mathrm{mmol})$ and mesyl chloride $(1.45 \mathrm{~g}, 12 \mathrm{mmol})$ were added at $-10^{\circ} \mathrm{C}$. The mixture was stirred at room temperature for $2 \mathrm{~h}$ and, then, washed with a saturated solution of $\mathrm{NaHCO}_{3}$ and concentrated in vacuo. The residue was purified by flash chromatography (dichloromethane/methanol 99:1 as eluent) to afford the mesylate $\mathbf{1 5}^{26}$ in $90 \%$ yield. A solution of $\mathbf{1 5}$ in $25 \mathrm{~mL}$ of triethylamine was then reacted with methyl hydroxylamine $(668 \mathrm{mg}$, $7.9 \mathrm{mmol}$ ) and left under reflux for $5 \mathrm{~h}$. The reaction mixture was evaporated and the residue was extracted with ether to afford compound 16 as an yellow oil (50\% yield). ${ }^{1} \mathrm{H}$ NMR $\left(\mathrm{CDCl}_{3}\right)$ : $\delta=5.80$ (bs s, OH), $4.30\left(\mathrm{~m}, 4 \mathrm{H}, \mathrm{CH}_{2} \mathrm{OP}\right), 3.32$ (d, $J=14.9 \mathrm{~Hz}$, $\left.\mathrm{CH}_{2} \mathrm{P}, 2 \mathrm{H}\right), 2.95\left(\mathrm{~s}, \mathrm{NCH}_{3}\right), 1.45(\mathrm{t}, J=7.0 \mathrm{~Hz}, 6 \mathrm{H}) .{ }^{13} \mathrm{C} \mathrm{NMR}\left(\mathrm{CDCl}_{3}\right)$ : $\delta=62.02\left(\mathrm{~d},{ }^{2} J_{\mathrm{POC}}=6.2 \mathrm{~Hz}\right), 57.99\left(\mathrm{~d},{ }^{1} J_{\mathrm{PC}}=162.0 \mathrm{~Hz}\right), 49.87(\mathrm{~d}$, $\left.{ }^{3} J_{\mathrm{PCNC}}=17.2 \mathrm{~Hz}\right), \quad 16.22 \quad\left(\mathrm{~d},{ }^{2} J_{\mathrm{POCC}}=6.2 \mathrm{~Hz}\right)$. Anal. Calcd for $\mathrm{C}_{6} \mathrm{H}_{16} \mathrm{NO}_{4} \mathrm{P}$ : C, 36.55; H, 8.18; N, 7.10. Found: C, 36.69; H, 8.17; $\mathrm{N}, 7 . .04$.

Phosphonated hydroxylamine $\mathbf{1 6}$ (330 mg, $1.6 \mathrm{mmol}$ ) in $15 \mathrm{~mL}$ of dichloromethane was oxidized with activated $\mathrm{MnO}_{2}(145 \mathrm{mg}$, $1.7 \mathrm{mmol}$ ) at room temperature overnight to afford, after filtration on celite, a residue which was purified by medium pressure chromatography to give nitrone 7 . Spectral data correspond perfectly with earlier reported data. ${ }^{23}$

\subsection{Synthesis of isoxazolidines 9 and 10}

A solution of $C$-diethoxyethylphosphoryl- $N$-methyl nitrone (7; $3.0 \mathrm{~g}, 22.9 \mathrm{mmol})$ and ethyl 2-acetyloxyacrylate $(8 ; 3.7 \mathrm{~g}, 23 \mathrm{mmol})$ in THF $(100 \mathrm{~mL})$ was stirred at reflux for $24 \mathrm{~h}$. The solvent was evaporated and the residue was purified by flash chromatography (dichloromethane/isopropanol 98:2). The product eluted first was the ethyl (3SR,5RS)-5-(acetyloxy)-3-(diethoxyphosphoryl)-2methyl-isoxazolidine-5-carboxylate 9; $18 \%$ yield; yellow oil. ${ }^{1} \mathrm{H}$
NMR $\left(\mathrm{CDCl}_{3}\right): \delta=4.28-4.12\left(\mathrm{~m}, 6 \mathrm{H}, 2 \times \mathrm{CH}_{2}-\mathrm{O}-\mathrm{P}+\mathrm{CH}_{2}-\mathrm{O}-\mathrm{C}\right)$, 3.23 (ddd, $J=9.1,6.9$ and $6.5 \mathrm{~Hz}, \mathrm{H}-\mathrm{C} 3$ ), 2.93 (ddd, $J=12.5,12.6$ and $9.1 \mathrm{~Hz}, \mathrm{H} \beta-\mathrm{C} 4), 2.84\left(\mathrm{~s}, 3 \mathrm{H}, \mathrm{CH}_{3}-\mathrm{N}\right), 2.81$ (ddd, $J=18.8,12.5$ and $6.9 \mathrm{~Hz}, \mathrm{H} \alpha-\mathrm{C} 4), 2.07\left(\mathrm{~s}, 3 \mathrm{H}, \mathrm{CH}_{3}-\mathrm{CO}\right), 1.31$ (t, $6 \mathrm{H}, J=6.5 \mathrm{~Hz}$ ), $1.24(\mathrm{t}, 3 \mathrm{H}, J=7.0 \mathrm{~Hz}) .{ }^{13} \mathrm{C}$ NMR $\left(\mathrm{CDCl}_{3}\right): \delta=170.16(\mathrm{~s}, \mathrm{C}=\mathrm{O})$, $165.50(\mathrm{~s}, \mathrm{C}=0), 102.19\left(\mathrm{~d},{ }^{3} J_{\mathrm{PCCC}}=9.5 \mathrm{~Hz}, \mathrm{C} 5\right), 64.57 \quad(\mathrm{~d}$, $\left.{ }^{1} J_{\mathrm{PC}}=163.1, \mathrm{C} 3\right), 63.61\left(\mathrm{~d},{ }^{2} \mathrm{~J} \mathrm{POC}=6.0 \mathrm{~Hz}\right), 62.71\left(\mathrm{~d},{ }^{2} J_{P O C}=7.8 \mathrm{~Hz}\right)$, $62.61\left(\mathrm{~s}, \mathrm{CH}_{2}-\mathrm{O}\right), 46.08\left(\mathrm{~s}, \mathrm{CH}_{3}-\mathrm{N}\right), 44.50\left(\mathrm{~d},{ }^{2} \mathrm{JPCC}_{\mathrm{PCC}}=1.5 \mathrm{~Hz}, \mathrm{C} 4\right)$, $20.84\left(\mathrm{~s}, \mathrm{CH}_{3}-\mathrm{C}=\mathrm{O}\right), 16.38\left(\mathrm{~d},{ }^{3} J_{P O C C}=6.0 \mathrm{~Hz}\right), 13.86\left(\mathrm{~s}, \mathrm{CH}_{3}\right) ;{ }^{31} \mathrm{P}$ NMR (121.5 MHz, $\left.\mathrm{CDCl}_{3}\right): \delta$ 22.77. Anal. Calcd for $\mathrm{C}_{13} \mathrm{H}_{24} \mathrm{NO}_{8} \mathrm{P}: \mathrm{C}$, 44.19; H, 6.85; N, 3.96. Found: C, 44.26; H, 6.88; N,3.94.

The fraction eluted second was the ethyl (3SR,5SR)-5-(acetyloxy)-3-(diethoxyphosphoryl)-2-methylisoxazolidine-5-carboxylate 10; $62 \%$ yield; yellow oil. ${ }^{1} \mathrm{H}$ NMR $\left(\mathrm{CDCl}_{3}\right): \delta=4.27-4.09(\mathrm{~m}, 6 \mathrm{H}$, $2 \times \mathrm{CH}_{2}-\mathrm{O}-\mathrm{P}+\mathrm{CH}_{2}-\mathrm{O}-\mathrm{C}$ ), 3.27 (ddd, $J=12.0,6.1$ and $1.5 \mathrm{~Hz}, \mathrm{H}-\mathrm{C} 3$ ), 2.96 (ddd, $J=16.5,13.0$ and $12.0 \mathrm{~Hz}, \mathrm{H} \beta-\mathrm{C} 4), 2.94$ (d, $J=0.9 \mathrm{~Hz}, 3 \mathrm{H}$, $\mathrm{CH}_{3}-\mathrm{N}$ ), 2.85 (ddd, $\left.J=13.0,6.1,4.3 \mathrm{~Hz}, \mathrm{H} \alpha-\mathrm{C} 4\right), 2.05$ (s, 3H, $\mathrm{CH}_{3}-$ CO), $1.32(\mathrm{t}, 6 \mathrm{H}, J=6.5 \mathrm{~Hz}), 1.23(\mathrm{t}, 3 \mathrm{H}, J=7.0 \mathrm{~Hz}) .{ }^{13} \mathrm{C} \mathrm{NMR}\left(\mathrm{CDCl}_{3}\right)$ $\delta=169.48(\mathrm{~s}, \mathrm{C}=\mathrm{O}), 164.84(\mathrm{~s}, \mathrm{C}=\mathrm{O}), 102.24\left(\mathrm{~d},{ }^{3} \mathrm{JPCC}_{\mathrm{PCC}}=13.5 \mathrm{~Hz}\right.$, C5), 64.00 (d, $J=6.0 \mathrm{~Hz}, \mathrm{C}-\mathrm{O}-\mathrm{P}), 62.78\left(\mathrm{~d},{ }^{1} \mathrm{~J}_{\mathrm{PC}}=171.7, \mathrm{C} 3\right), 62.70$ (d, J = 8.2 Hz, C-O-P), $62.63\left(\mathrm{~s}, \mathrm{CH}_{2}-\mathrm{O}\right), 49.24$ (d, J = 4.5 Hz, C-NC-P), $43.01\left(\mathrm{~d},{ }^{2} J_{\mathrm{PCC}}=1.5 \mathrm{~Hz}, \mathrm{C} 4\right), 21.07\left(\mathrm{~s}, \mathrm{CH}_{3}-\mathrm{C}=0\right), 16,38$ (d, $J=6.0 \mathrm{~Hz}), 13.86\left(\mathrm{~s}, \mathrm{CH}_{3}\right) ;{ }^{31} \mathrm{P} \mathrm{NMR}\left(121.5 \mathrm{MHz}, \mathrm{CDCl}_{3}\right): \delta 21.66$. Anal. Calcd for $\mathrm{C}_{13} \mathrm{H}_{24} \mathrm{NO}_{8} \mathrm{P}$ : C, 44.19; $\mathrm{H}, 6.85 ; \mathrm{N}, 3.96$. Found: $\mathrm{C}$, 44.22; H,6.87; N, 3.99 .

\subsection{General procedure for the preparation of truncated phosphonated $\mathrm{N}, \mathrm{O}$-psiconucleosides 11 and 12}

A suspension of nucleobases $(2 \mathrm{mmol})$ in dry acetonitrile $(30 \mathrm{~mL})$ was treated with bis(trimethylsilyl)acetamide $(1.5 \mathrm{~mL}$, $6 \mathrm{mmol}$ ) and left under stirring until the solution was clear. A solution of a mixture of isozaxolidines $\mathbf{9}$ and $\mathbf{1 0}(282 \mathrm{mg}, 1 \mathrm{mmol})$ in dry acetonitrile $(10 \mathrm{~mL})$ and trimethylsilyl triflate $(72 \mu \mathrm{L}$, $0.4 \mathrm{mmol}$ ) was then added, and the reaction mixture was heated at $70^{\circ} \mathrm{C}$ for $5 \mathrm{~h}$. After being cooled at $0{ }^{\circ} \mathrm{C}$, the solution was carefully neutralized by addition of aqueous $5 \%$ sodium bicarbonate and then concentrated in vacuo. After addition of dichloromethane $(20 \mathrm{~mL})$, the organic phase was separated, washed with water $(2 \times 10 \mathrm{~mL})$, dried over sodium sulfate, filtered, and evaporated to dryness. The ${ }^{1} \mathrm{H}$ NMR spectrum of the crude reaction mixture shows the presence of $\beta$-anomers as major adducts, while the $\alpha$ anomers are present only in low amount. The residue was purified by MPLC on a silica gel column using as eluent a mixture of $\mathrm{CH}_{2} \mathrm{Cl}_{2}$ / $\mathrm{Me}_{2} \mathrm{CHOH}$ 98:2 to afford $\beta$-nucleosides 11a-d and $\alpha$-nucleosides 12a-d.

\subsubsection{Ethyl (3SR,5RS)-3-(diethoxyphosphoryl)-2-methyl-5-(5- methyl-2,4-dioxo-3,4-dihydro-pyrimidin-1(2H)-yl)isoxazolidi- ne-5-carboxylate 11a}

Yield: 43.2\%; white solid, mp $193-195{ }^{\circ} \mathrm{C} .{ }^{1} \mathrm{H}$ NMR $\left(\mathrm{CDCl}_{3}\right)$ : $\delta=8.71(\mathrm{~s}, \mathrm{NH}, 1 \mathrm{H}), 7.52(\mathrm{br} \mathrm{q}, J=1.0 \mathrm{~Hz}, \mathrm{CH}=1 \mathrm{H}), 4.26(\mathrm{q}$, $J=7.0 \mathrm{~Hz}, 2 \mathrm{H}), 4.30-4.08(\mathrm{~m}, 4 \mathrm{H}), 3.84$ (ddd, $J=14.5,8.5$ and $4.0 \mathrm{~Hz}, \mathrm{H} \alpha-\mathrm{C}^{\prime}, 1 \mathrm{H}$ ), 3.25 (ddd, $J=10.5,8.5$ and $3.0 \mathrm{~Hz}, \mathrm{H}-\mathrm{C}^{\prime}$, $1 \mathrm{H}$ ), $3.06(\mathrm{~s}, 3 \mathrm{H}), 2.88$ (ddd, $J=16.5,14.5$ and $10.5 \mathrm{~Hz}, \mathrm{H} \beta-\mathrm{C}^{\prime}$, $1 \mathrm{H}), 1.97(\mathrm{~d}, J=1.0 \mathrm{~Hz}, 3 \mathrm{H}), 1.34(\mathrm{t}, J=7.0 \mathrm{~Hz}, 3 \mathrm{H}), 1.28(\mathrm{t}$, $J=7.0 \mathrm{~Hz}, 3 \mathrm{H}), 1.25(\mathrm{t}, J=7.0 \mathrm{~Hz}, 3 \mathrm{H}) .{ }^{13} \mathrm{C} \mathrm{NMR}\left(\mathrm{CDCl}_{3}\right): \delta=164.7$, 164.2 (C4), 150.3 (C2), 134.7 (C6), 109.3 (C5), 92.5 (d, $\left.{ }^{3} J_{P C C C}=11.5 \mathrm{~Hz}, C 1^{\prime}\right), 65.2\left(\mathrm{~d},{ }^{1} \mathrm{~J}\right.$ PC $\left.=155.2 \mathrm{~Hz}, \mathrm{C} 4^{\prime}\right), 63.5\left(\mathrm{~d},{ }^{2} \mathrm{~J}\right.$ POC $=6.0 \mathrm{~Hz}), 63.3\left(\mathrm{CH}_{2}-\mathrm{O}\right), 62.5\left(\mathrm{~d},{ }^{2} J_{\mathrm{POC}}=6.8 \mathrm{~Hz}\right), 46.2\left(\mathrm{CH}_{3} \mathrm{~N}\right)$, $45.4\left(\mathrm{D},{ }^{2} \mathrm{~J}_{\mathrm{PCC}}=4 \mathrm{~Hz}, \quad \mathrm{C5}^{\prime}\right), 16.4 \quad\left(\mathrm{~d},{ }^{3} J_{\mathrm{POCC}}=2.2 \mathrm{~Hz}\right), 16.3(\mathrm{~d}$, $\left.{ }^{3} J_{\text {POCC }}=2.2 \mathrm{~Hz}\right), 13.8\left(\mathrm{CH}_{3}-\mathrm{CH}=\right), 12.7 .{ }^{31} \mathrm{P}$ NMR $(121.5 \mathrm{MHz}$, $\mathrm{CDCl}_{3}$ ): $\delta$ 21.52. Anal. Calcd for $\mathrm{C}_{16} \mathrm{H}_{26} \mathrm{~N}_{3} \mathrm{O}_{8} \mathrm{P}: \mathrm{C}, 45.82 ; \mathrm{H}, 6.25 ; \mathrm{N}$, 10.02. Found: C, 45.86; H, 6.23; N, 10.01 . 
4.3.2. Ethyl (3SR,5RS)-3-(diethoxyphosphoryl)-5-(5-fluoro-2,4dioxo-3,4-dihydropyrimidin-1(2H)-yl)-2-methylisoxazolidine5-carboxylate 11b

Yield: 68\%; white solid, mp 200-201 ${ }^{\circ} \mathrm{C} .{ }^{1} \mathrm{H}$ NMR $\left(\mathrm{CDCl}_{3}\right)$ : $\delta=8.91(\mathrm{~s}, 1 \mathrm{H}), 7.77(\mathrm{~d}, J=6.5 \mathrm{~Hz}, 1 \mathrm{H}), 4.30-4.10(\mathrm{~m}, 6 \mathrm{H}), 3.83$ (ddd, $J=14.0,8.5$ and $4.0 \mathrm{~Hz}, 1 \mathrm{H}$ ), 3.25 (ddd, $J=10.0,8.5$ and $3.0 \mathrm{~Hz}, 1 \mathrm{H}$ ), $2.95(\mathrm{~s}, 3 \mathrm{H}), 2.93$ (ddd, $J=16.5,14.0$ and $10.0 \mathrm{~Hz}$, $1 \mathrm{H}), 1.35(\mathrm{t}, J=7.5 \mathrm{~Hz}, 3 \mathrm{H}), 1.28(\mathrm{~m}, 6 \mathrm{H}) .{ }^{13} \mathrm{C}$ NMR $(125 \mathrm{MHz}$, $\left.\mathrm{CDCl}_{3}\right): \delta=164.12,156.93(\mathrm{~d}, J=26.7 \mathrm{~Hz}), 148.74,139.90$ (d, $J=235.1 \mathrm{~Hz}), 123.73(\mathrm{~d}, J=35.2 \mathrm{~Hz}), 92.63(\mathrm{~d}, J=10.6 \mathrm{~Hz}), 65.13$ (d, $J=163.7 \mathrm{~Hz}), 63.43$ (d, $J=7.3 \mathrm{~Hz}), 63.35,62.61(\mathrm{~d}, J=6.8 \mathrm{~Hz})$, 46.20, 45.17, 16.41, 16.21, 13.84. Anal. Calcd for $\mathrm{C}_{15} \mathrm{H}_{23} \mathrm{FN}_{3} \mathrm{O}_{8} \mathrm{P}: \mathrm{C}$, 42.56; H, 5.48; N, 9.93. Found: C, 42.59; H, 5.50; N, 9.91.

4.3.3. Ethyl (3SR,5RS)-3-(diethoxyphosphoryl)-5-(2,4-dioxo-3,4dihydropyrimidin-1(2H)-yl)-2-methylisoxazolidine-5-

carboxylate 11c

Yield: 47.61\%; white solid, $\mathrm{mp} 171-174{ }^{\circ} \mathrm{C} .{ }^{1} \mathrm{H}$ NMR $\left(\mathrm{CDCl}_{3}\right)$ : $\delta=8.61$ (bs s, $1 \mathrm{H}$ ), 7.72 (d, $J=8.2 \mathrm{~Hz}, 1 \mathrm{H}), 5.77$ (d, $J=8.2 \mathrm{~Hz}, 1 \mathrm{H}$ ), 4.37-4.02 (m, 6H), 3.92 (ddd, $J=14.2,8.5$ and $4.1 \mathrm{~Hz}, \mathrm{H \alpha}-\mathrm{C}^{\prime}$, $1 \mathrm{H}$ ), 3.31 (ddd, $J=10.1,8.5$ and $2.7 \mathrm{~Hz}, \mathrm{H}-\mathrm{C} 4^{\prime}, 1 \mathrm{H}$ ), 3.00 (ddd, $J=16.3,14.2$ and $\left.\left.10.1 \mathrm{~Hz}, \mathrm{H} \beta-\mathrm{C}^{\prime}, 1 \mathrm{H}\right), 2.98(\mathrm{~s}, 3 \mathrm{H}),\right), 1.34(\mathrm{t}$, $J=7.1 \mathrm{~Hz}, \quad 3 \mathrm{H}), 1.32(\mathrm{~m}, 6 \mathrm{H}) .{ }^{13} \mathrm{C}$ NMR $\left(125 \mathrm{MHz}, \mathrm{CDCl}_{3}\right)$ : $\delta=164.42,163.31,150.28,139.01,100.96,92.84(\mathrm{~d}, J=12.0 \mathrm{~Hz})$, $65.04(\mathrm{~d}, J=164.9 \mathrm{~Hz}), 63.69(\mathrm{~d}, J=6.0 \mathrm{~Hz}), 63.44,62.49$ (d, $J=7.2 \mathrm{~Hz}), 46.11,45.28,16.50,16.41,16.31,13.84$. Anal. Calcd for $\mathrm{C}_{15} \mathrm{H}_{24} \mathrm{~N}_{3} \mathrm{O}_{8} \mathrm{P}: \mathrm{C}, 44.45 ; \mathrm{H}, 5,97 ; \mathrm{N}, 10.37$. Found: $\mathrm{C}, 44.41 ; \mathrm{H}$, $5.96 \mathrm{~N}, 10.40$.

\subsubsection{Ethyl (3SR,5RS)-5-[4-(acetylamino)-2-oxopyrimidin- 1(2H)-yl]-3-(diethoxyphosphoryl)-2-methylisoxazolidine-5- carboxylate 11d}

Yield: 41.27\%; yellow sticky oil. ${ }^{1} \mathrm{H}$ NMR $\left(\mathrm{CDCl}_{3}\right): \delta=8.91$ (bs s, $1 \mathrm{H}), 8.10(\mathrm{~d}, J=7.6 \mathrm{~Hz}, 1 \mathrm{H}), 7.51(\mathrm{~d}, J=7.6 \mathrm{~Hz}, 1 \mathrm{H}), 4.22-4.08(\mathrm{~m}$, $6 \mathrm{H}$ ), 3.95 (ddd, $J=13.5,8.4$ and $3.4 \mathrm{~Hz}, \mathrm{H \alpha}-\mathrm{C}^{\prime}, 1 \mathrm{H}$ ), 3.28 (ddd, $J=11.2,8.4$ and $\left.2.9 \mathrm{~Hz}, \mathrm{H}-\mathrm{C}^{\prime}, 1 \mathrm{H}\right), 3.07$ (s, 3H), 2.92 (ddd, $J=16.2,13.5$ and $\left.10.3 \mathrm{~Hz}, \mathrm{H} \beta-\mathrm{C}^{\prime}, 1 \mathrm{H}\right), 2.26(\mathrm{~s}, 3 \mathrm{H}), 1.35(\mathrm{t}$, $J=7.1 \mathrm{~Hz}, 3 \mathrm{H}), 1.33(\mathrm{~m}, 6 \mathrm{H}) .{ }^{13} \mathrm{C}$ NMR $\left(125 \mathrm{MHz}, \mathrm{CDCl}_{3}\right)$ : $\delta=170.96,164.32,163.51,155.18,143.69,95.92,92.84$ (d, $J=10.6 \mathrm{~Hz}), 65.23(\mathrm{~d}, J=162.6 \mathrm{~Hz}), 63.61(\mathrm{~d}, J=69 \mathrm{~Hz}), 63.15$, $62.41(\mathrm{~d}, J=6.6 \mathrm{~Hz}), 46.12,44.86,24.76,16.41(\mathrm{~d}, J=4.4 \mathrm{~Hz})$, $16.30(\mathrm{~d}, J=5.4 \mathrm{~Hz}), 13.77$. Anal. Calcd for $\mathrm{C}_{17} \mathrm{H}_{27} \mathrm{~N}_{4} \mathrm{O}_{8} \mathrm{P}$ : C, 45.74; $\mathrm{H}, 6.10$; N, 12.55. Found: C, 45.78; $\mathrm{H}, 6,16 \mathrm{~N}, 12.53$.

4.3.5. Ethyl (3SR,5RS)-5-[4-amino-2-oxopyrimidin-1(2H)-yl]-3(diethoxyphosphoryl)-2-methylisoxazolidine-5-carboxylate 11e

Yield: 41.42\%; yellow sticky oil. ${ }^{1} \mathrm{H}$ NMR $\left(\mathrm{CDCl}_{3}\right): \delta=8.15(\mathrm{~d}$, $J=7.5 \mathrm{~Hz}, 1 \mathrm{H}$ ), 7.50 (d, $J=7.5 \mathrm{~Hz}, 1 \mathrm{H}$ ), 6.70 (bs s, $1 \mathrm{H}$ ), $4.20-4.08$ (m, 6H), 4.01 (ddd, $J=13.4,8.2$ and $3.4 \mathrm{~Hz}, \mathrm{H \alpha}-\mathrm{C}^{\prime}, 1 \mathrm{H}$ ), 3.30 (ddd, $J=11.2,8.2$ and $3.0 \mathrm{~Hz}, \mathrm{H}-\mathrm{C}^{\prime}, 1 \mathrm{H}$ ), 3.02(s, 3H), 2.80 (ddd, $J=16.2,13.4$ and $\left.10.3 \mathrm{~Hz}, \mathrm{H} \beta-\mathrm{C}^{\prime}, 1 \mathrm{H}\right), 1.35$ (t, $\left.J=7.1 \mathrm{~Hz}, 3 \mathrm{H}\right)$, $1.29(\mathrm{~m}, 6 \mathrm{H}) .{ }^{13} \mathrm{C}$ NMR $\left(125 \mathrm{MHz}, \mathrm{CDCl}_{3}\right): \delta=165.06,163.50$, 154.89, 142.12, 96.28, 94.544 (d, J=10.4 Hz), 66.02 (d, $J=162.4 \mathrm{~Hz}), 64.05(\mathrm{~d}, J=67 \mathrm{~Hz}), 63.14,62.38$ (d, $J=6.4 \mathrm{~Hz})$, $48.89,46.85,15.89$ (d, $J=4.4 \mathrm{~Hz}), 16.22$ (d, $J=5.5 \mathrm{~Hz}$ ), 12.70. Ana1.Calcd for $\mathrm{C}_{15} \mathrm{H}_{25} \mathrm{~N}_{4} \mathrm{O}_{7} \mathrm{P}$ : C, 44.56; $\mathrm{H}, 6.20, \mathrm{~N}, 13.88$. Found: C, 44.59; H, $6.29 \mathrm{~N}, 13.84$.

\subsubsection{Ethyl (3SR,5SR)-3-(diethoxyphosphoryl)-2-methyl-5-(5-} methyl-2,4-dioxo-3,4-dihydro-pyrimidin-1(2H)-yl)isoxazolidine-5-carboxylate 12a

Yield: 28.8\%; white solid, $\mathrm{mp} 198-200{ }^{\circ} \mathrm{C} .{ }^{1} \mathrm{H}$ NMR $\left(\mathrm{CDCl}_{3}\right)$ : $\delta=8.23$ (br s, NH, 1H), 7.61 (br q, $J=0.9 \mathrm{~Hz}, \mathrm{CH}=, 1 \mathrm{H}$ ), 4.30-4.11 $(\mathrm{m}, 6 \mathrm{H}), 3.84$ (ddd, $J=15.0,10.2$ and $2.8 \mathrm{~Hz}, \mathrm{H \alpha}-\mathrm{C}^{\prime}, 1 \mathrm{H}$ ), 3.15$3.08\left(\mathrm{~m}, \mathrm{H}-\mathrm{C}^{\prime}\right.$ and $\left.\mathrm{H} \beta-\mathrm{C}^{\prime}, 2 \mathrm{H}\right), 3.13(\mathrm{~s}, 3 \mathrm{H}), 1.97(\mathrm{~d}, J=0.9 \mathrm{~Hz}$, $3 \mathrm{H}), 1.34(\mathrm{t}, J=7.0 \mathrm{~Hz}, 3 \mathrm{H}), 1.26(\mathrm{t}, J=7.0 \mathrm{~Hz}, 3 \mathrm{H}), 1.24(\mathrm{t}$,
$J=7.0 \mathrm{~Hz}, 3 \mathrm{H}) .{ }^{13} \mathrm{C} \mathrm{NMR}\left(\mathrm{CDCl}_{3}\right): \delta=165.19,163.46$ (C4), 150.13 (C2), 134.61 (C6), 109.92 (C5), 92.69 (d, $\left.J=14.2 \mathrm{~Hz}, \mathrm{C} 1^{\prime}\right), 63.33$ $\left(\mathrm{CH}_{2}-\mathrm{O}\right), 63.24(\mathrm{~d}, J=6.9 \mathrm{~Hz}), 62.15\left(\mathrm{~d}, J=163.2 \mathrm{~Hz}, \mathrm{C}^{\prime}\right), 62.70$ $(\mathrm{d}, J=6.9 \mathrm{~Hz}), 45.43\left(\mathrm{CH}_{3} \mathrm{~N}\right), 43.95\left(\mathrm{C}^{\prime}\right), 16.43(\mathrm{~d}, J=4.5 \mathrm{~Hz})$, $13.95(\mathrm{~d}, \quad J=7.5 \mathrm{~Hz}), \quad 13.80 \quad\left(\mathrm{CH}_{3}-\mathrm{CH}=\right), \quad 12.86 .{ }^{31} \mathrm{P} \quad \mathrm{NMR}$ $\left(121.5 \mathrm{MHz}, \mathrm{CDCl}_{3}\right): \delta$ 20.79. Anal. Calcd for $\mathrm{C}_{16} \mathrm{H}_{26} \mathrm{~N}_{3} \mathrm{O}_{8} \mathrm{P}: \mathrm{C}$, 45.82; H, 6.25; N, 10.02. Found: C, 45.87; H, 6.27; N, 9.98.

4.3.7. Ethyl (3SR,5SR)-3-(diethoxyphosphoryl)-5-(5-fluoro-2,4dioxo-3,4-dihydropyrimidin-1(2H)-yl)-2-methylisoxazolidine5-carboxylate 12b

Yield: $12 \%$; white solid, mp $193-195{ }^{\circ} \mathrm{C} .{ }^{1} \mathrm{H}$ NMR $\left(\mathrm{CDCl}_{3}\right)$ : $\delta=8.65$ (bs s, $1 \mathrm{H}), 7.86(\mathrm{~d}, J=6.6 \mathrm{~Hz}), 4.29-4.14(\mathrm{~m}, 6 \mathrm{H}), 3.81$ (ddd, $J=15.0,14.6$ and $\left.1.3 \mathrm{~Hz}, \mathrm{H}-\mathrm{C}^{\prime}, 1 \mathrm{H}\right), 3.18-3.02(\mathrm{bm}, \mathrm{H}-\mathrm{C} 4$ and $\left.\mathrm{H}_{-}-\mathrm{C}^{\prime}, 2 \mathrm{H}\right), 3.13\left(\mathrm{~s}, \mathrm{~N}-\mathrm{CH}_{3}, 3 \mathrm{H}\right), 1.38(\mathrm{t}, J=8.5 \mathrm{~Hz}, 3 \mathrm{H}), 1.35$ $(\mathrm{t}, J=8.2 \mathrm{~Hz}, 3 \mathrm{H}), 1.25(\mathrm{t}, J=8.2 \mathrm{~Hz}, 3 \mathrm{H}) .{ }^{13} \mathrm{C} \mathrm{NMR}\left(\mathrm{CDCl}_{3}\right)$ : $\delta=164.66,159.82(\mathrm{~d}, J=30.4 \mathrm{~Hz}), 156.20,139.95(\mathrm{~d}, J=237.0 \mathrm{~Hz})$, $123.60(\mathrm{~d}, J=35.8 \mathrm{~Hz}), 92.55(\mathrm{~d}, J=12.5 \mathrm{~Hz}), 64.07(\mathrm{~d}, J=6.5 \mathrm{~Hz})$, $63.88(\mathrm{~d}, J=175.0 \mathrm{~Hz}), 63.80,62.90(\mathrm{~d}, J=6.5 \mathrm{~Hz}), 53.43,42.62$, 16.48, 16.37, 13.87. Anal. Calcd for $\mathrm{C}_{15} \mathrm{H}_{23} \mathrm{FN}_{3} \mathrm{O}_{8} \mathrm{P}$ : C, 42.56; $\mathrm{H}$, 5.48; N, 9.93. Found: C, 42.53; H, 5.51; N, 9.94 .

\subsubsection{Ethyl (3SR,5SR)-3-(diethoxyphosphoryl)-5-(2,4-dioxo-3,4- dihydropyrimidin-1(2H)-yl)-2-methylisoxazolidine-5- carboxylate 12c}

Yield: $23.8 \%$; white solid, mp $178-180{ }^{\circ} \mathrm{C} .{ }^{1} \mathrm{H}$ NMR $\left(\mathrm{CDCl}_{3}\right)$ : $\delta=8.49($ bs s, $1 \mathrm{H}), 7.81(\mathrm{~d}, J=8.3 \mathrm{~Hz}, 1 \mathrm{H}), 5.79(\mathrm{~d}, J=8.3 \mathrm{~Hz}, 1 \mathrm{H})$, 4.37-4.10 (m, 6H), 4.02 (ddd, $J=14.3,8.2$ and $1.3 \mathrm{~Hz}, \mathrm{H} \alpha-\mathrm{C}^{\prime}$, $1 \mathrm{H}), 3.16-3.05\left(\mathrm{~m}, \mathrm{H}-\mathrm{C} 4^{\prime}\right.$, and $\left.\mathrm{H}-\mathrm{C}^{\prime}, 2 \mathrm{H}\right), 3.13(\mathrm{~s}, 3 \mathrm{H}), 1.35(\mathrm{t}$, $J=7.2 \mathrm{~Hz}, 3 \mathrm{H}), 1.26(\mathrm{t}, J=7.0 \mathrm{~Hz}, 3 \mathrm{H}), 1.24(\mathrm{t}, J=7.0 \mathrm{~Hz}, 3 \mathrm{H}) .{ }^{13} \mathrm{C}$ NMR $\left(125 \mathrm{MHz}, \mathrm{CDCl}_{3}\right): \delta=169.33,166.44,150.16,138.88$, 101.53, 90.77 (d, $J=12.3 \mathrm{~Hz}), 64.07$ (d, $J=6.0 \mathrm{~Hz}), 63.14$ (d, $J=176.8 \mathrm{~Hz}), 63.31,62.81(\mathrm{~d}, J=7.1 \mathrm{~Hz}), 47.27,42.67,16.41$ (d, $J=4.5 \mathrm{~Hz}$ ), 14.13, 13.86. Anal. Calcd for $\mathrm{C}_{15} \mathrm{H}_{24} \mathrm{~N}_{3} \mathrm{O}_{8} \mathrm{P}: \mathrm{C}, 44.45 ; \mathrm{H}$, 5,97; N, 10.37. Found: C, 44.47; H, 5.94 N, 10.41.

\subsubsection{Ethyl (3SR,5SR)-5-[4-(acetylamino)-2-oxopyrimidin-} 1(2H)-yl]-3-(diethoxyphosphoryl)-2-methylisoxazolidine-5carboxylate 12d

Yield: $19.84 \%$; yellow sticky oil. ${ }^{1} \mathrm{H}$ NMR $\left(\mathrm{CDCl}_{3}\right): \delta=8.89$ (bs s, $1 \mathrm{H}), 7.75(\mathrm{~d}, J=7.3 \mathrm{~Hz}, 1 \mathrm{H}), 7.52(\mathrm{~d}, J=7.3 \mathrm{~Hz}, 1 \mathrm{H}), 4.27-4.03(\mathrm{~m}$, $6 \mathrm{H}$ ), 4.02 (ddd, $J=13.9,7.8$ and $1.7 \mathrm{~Hz}, \mathrm{H \alpha}-\mathrm{C}^{\prime}, 1 \mathrm{H}$ ), 3.33-3.22 (m, H-C4', and $\left.\mathrm{H}-\mathrm{C5}^{\prime}, 2 \mathrm{H}\right), 3.08(\mathrm{~s}, 3 \mathrm{H}), 2.24(\mathrm{~s}, 3 \mathrm{H}), 2.24(\mathrm{~s}, 3 \mathrm{H})$, $1.29(\mathrm{t}, J=7.2 \mathrm{~Hz}, 3 \mathrm{H}), 1.27(\mathrm{t}, J=7.2 \mathrm{~Hz}, 3 \mathrm{H}), 1.25(\mathrm{t}, J=7.2 \mathrm{~Hz}$, $3 \mathrm{H}) .{ }^{13} \mathrm{C} \mathrm{NMR}\left(125 \mathrm{MHz}, \mathrm{CDCl}_{3}\right): \delta=170.16,164.30,162.22$, $155.10,143.87,113.88,93 . .82(\mathrm{~d}, J=11.9 \mathrm{~Hz}), 65.85 \quad(\mathrm{~d}$, $J=105.0 \mathrm{~Hz}), 63.53(\mathrm{~d}, J=6.0 \mathrm{~Hz}), 63.21,62.42(\mathrm{~d}, J=6.5 \mathrm{~Hz})$, 46.17, 44.87, 24.95, 16.39 (d, J=6.3 Hz), 16.41, 13.96 (d, $J=16.0 \mathrm{~Hz}$ ). Anal. Calcd for $\mathrm{C}_{17} \mathrm{H}_{27} \mathrm{~N}_{4} \mathrm{O}_{8} \mathrm{P}: \mathrm{C}, 45.74 ; \mathrm{H}, 6.10 ; \mathrm{N}$, 12.55. Found: C, 45.70; H, 6.14; N, 12.58 .

\subsection{Biological assay}

The compounds were tested for their inhibitory activity on HTLV-1 and HIV infection. HTLV-1 infection was carried out as previously shown. ${ }^{26}$ Peripheral blood mononuclear cells were co-cultivated with a HTLV-1 chronically infected cell line and infection was evaluated as production of the viral core protein p19. HIV infection was carried on by using a stable $T$ cell line (CEM) containing a plasmid encoding a green fluorescence protein (GFP) driven by the HIV-1 long terminal repeat. ${ }^{27}$ Infection was carried on as previouslyb shown with some modification. ${ }^{28}$ Briefly, $5 \times 10^{5}$ CEM-GFP were infected with a volume of supernatant from HIV chronically infected $\mathrm{H} 9$ cells equivalent to $20 \mathrm{ng} / \mathrm{mL}$ of HIV p24, for $2 \mathrm{~h}$ in $100 \mu \mathrm{l} \mathrm{CM}$ in presence of $1000,100,10$ and $1 \mu \mathrm{M}$ concentration of compounds. Then medium was added and the 
cultures were incubaterd for $72 \mathrm{~h}$. The inhibition was assessed on the basis of GFP expression in the different culture conditions. Citotoxicity assays were performed by MTS assay kit (Promega Corporation, Madison, Winsconsin).BrieflyInhibition of cell metabolic activity revealed by reduction of the oxidative burst was detected through formazan product formation, using a commercial colorimetric kit (MTS [3,4-(5-dimethylthiazol-2-yl)-5-(3-carboxymethoxyphenyl)-2-(4-sulfophenyl)-2H-tetrazolium salt]) (Cell Titer 96 Aqueous One Solution; Promega). The assay was performed by seeding $1 \times 104$ MOLT- 3 cells in the presence or absence of the different compounds at concentrations ranging from 1000 to $1 \mu \mathrm{M}$.

\section{Acknowledgments}

This work was partially supported by CINMPIS and MIUR (PRIN) and by the Istituto Superiore di Sanita' (AIDS Project) to B. Macchi contract N $40 \mathrm{H} 44$.

\section{Supplementary data}

Supplementary data associated with this article can be found, in the online version, at http://dx.doi.org/10.1016/j.bmc.2012.03.047. These data include MOL files and InChiKeys of the most important compounds described in this article.

\section{References and notes}

1. Itoh, Y.; Haraguchi, K.; Tanaka, H.; Gen, E.; Miyasaka, T. J. Org. Chem. 1995, 60, 656.

2. McCarthy, J. R.; Robins, R. K. J. Am. Chem. Soc. 1968, 90, 4993.

3. Prisbe, E. J.; Smejkal, J.; Verheyden, J. P. H.; Moffat, J. G. J. Org. Chem. 1976, 41, 1836.

4. Sukeda, M.; Shuto, S.; Sugimoto, I.; Ichikawa, S.; Matsuda, A. J. Org. Chem. 2000, $65,8988$.

5. Chiacchio, U.; Corsaro, A.; Iannazzo, D.; Piperno, A.; Rescifina, A.; Romeo, R.; Romeo, G. Tetrahedron Lett. 2001, 42, 1777.

6. Chiacchio, U.; Corsaro, A.; Iannazzo, D.; Piperno, A.; Pistarà, V.; Rescifina, A Romeo, R.; Sindona, G.; Romeo, G. Tetrahedron: Asymmetry 2003, 14, 2717.

7. Chiacchio, U.; Rescifina, A.; Saita, M. G.; Iannazzo, D.; Romeo, G.; Mates, J.; Tejero, T.; Merino, P. J. Org. Chem. 2005, 70, 8991
8. Merino, P.; Tejero, T.; Unzurrunzaga, F. J.; Franco, S.; Chiacchio, U.; Saita, M. G.; Iannazzo, D.; Piperno, A.; Romeo, G. Tetrahedron: Asymmetry 2005, 16, 3865

9. Romeo, G.; Chiacchio, U.; Corsaro, A.; Merino, P. Chem. Rev. 2010, 110, 3337.

10. Romeo, G.; Iannazzo, D.; Piperno, A.; Romeo, R.; Corsaro, A.; Rescifina, A.; Chiacchio, U. Mini Rev. Org. Chem. 2005, 2, 59.

11. Mannucci, V.; Cordero, F. M.; Piperno, A.; Romeo, G.; Brandi, A. Tetrahedron: Asymmetry 2008, 19, 1204.

12. Iannazzo, D.; Piperno, A.; Pistara, V.; Rescifina, A.; Romeo, R. Tetrahedron 2002, 58,581 .

13. Chiacchio, U.; Corsaro, A.; Pistarà, V.; Rescifina, A.; Iannazzo, D.; Piperno, A.; Romeo, G.; Romeo, R.; Grassi, G. Eur. J. Org. Chem. 2002, 7, 1206.

14. Saita, M. G.; Chiacchio, U.; Iannazzo, D. Corsaro, A.; Merino, P.; Piperno, A. Previtera, T.; Rescifina, A.; Romeo, G.; Romeo, R. Nucleosides Nucleotides Nucleic Acids 2003, 22, 739.

15. Chiacchio, U.; Borrello, L.; Iannazzo, D.; Merino, P.; Piperno, A.; Rescifina, A.; Richichi, B.; Romeo, G. Tetrahedron: Asymmetry 2003, 14, 2419.

16. Camps, P.; Gomez, T.; Munoz-Torrero, D.; Rull, J.; Sanchez, L.; Boschi, F.; Comes- Franchini, M.; Ricci, A.; Calvet, T.; Font-Bardia, M.; De Clercq, E.; Naesens, L. J. Org. Chem. 2008, 73, 6657.

17. Chiacchio, U.; Corsaro, A.; Iannazzo, D.; Piperno, A.; Pistarà, V.; Rescifina, A.; Romeo, R.; Valveri, V.; Mastino, A.; Romeo, G. J. Med. Chem. 2003, 46, 3696.

18. Chiacchio, U.; Borrello, L.; Crispino, L.; Rescifina, A.; Merino, P.; Macchi, B.; Balestrieri, E.; Mastino, A.; Piperno, A.; Iannazzo, D.; Romeo, G. J. Med. Chem. 2009, 52, 4054

19. Romeo, G.; Iannazzo, D.; Piperno, A.; Romeo, R.; Saglimbeni, M.; Chiacchio, M. A.; Balestrieri, E.; Macchi, B.; Mastino, A. Bioorg. Med. Chem. 2006, 14, 3818.

20. Chiacchio, U.; Rescifina, A.; Iannazzo, D.; Piperno, A.; Romeo, R.; Borrello, L.; Sciortino, M. T.; Balestrieri, E.; Macchi, B.; Mastino, A.; Romeo, G. J. Med. Chem. 2007, 50, 3747 .

21. Piperno, A.; Giofrè, S. V.; Iannazzo, D.; Romeo, R.; Romeo, G.; Chiacchio, U.; Rescifina, A.; Piotrowska, D. G. J. Org. Chem. 2010, 75, 2798.

22. Palmer, S.; Margot, N.; Gilbert, H.; Shaw, N.; Buckheit, R., Jr.; Miller, M. AIDS Res. Hum. Retroviruses 2001, 17, 1167.

23. Meier, C.; Balzarini, J. Antiviral Res. 2006, 71, 282; (b) Vanpouille, C.; Lisco, A.; Derudas, M.; Saba, E.; Grive, J.-C.; Brichacek, B.; Scrimieri, F.; Schinazi, R.; Schols, D.; McGuigan, C.; Balzarini, J.; Margolis, L. J. Infect. Dis. 2010, 201, 635.

24. Piotrowska, D. G. Tetrahedron Lett. 2006, 47, 5363.

25. Monnin, J. Helvetica Chim. Acta 1956, 39, 1721.

26. Balestrieri, E.; Matteucci, C.; Ascolani, A.; Piperno, A.; Romeo, R.; Romeo, G.; Chiacchio, U.; Mastino, A.; Macchi, B. Antimicrob. Agents Chemother. 2008, 52, 54.

27. Gervaix, A.; West, D.; Leoni, L. M.; Richman, D. D.; Wong-Staal, F.; Corbeil, J. Proc. Natl. Acad. Sci. U.S.A. 1997, 94, 4653.

28. Balestrieri, E.; Pizzimenti, F.; Ferlazzo, A.; Giofrè, S. V.; Iannazzo, D.; Piperno, A. Romeo, R.; Chiacchio, M. A.; Mastino, A.; Macchi, B. Bioorg. Med. Chem. 2011, 19, 2084 